\title{
Pelatihan Musik dan Tari Sigeh Penguten untuk Forum Musyawarah Guru Mata Pelajaran (MGMP) Seni Budaya Tingkat SMP Se-Kabupaten Lampung Utara
}

\author{
Nabilla Kurnia Adzan ${ }^{1 *}$, Erizal Barnawi ${ }^{2}$, Dwi Tiya Juwita ${ }^{1}$ \\ ${ }^{1}$ Pendidikan Tari, Universitas Lampung, Bandar Lampung, 35145, Lampung, Indonesia \\ 2 Pendidikan Musik, Universitas Lampung, Bandar Lampung, 35145, Lampung, Indonesia
}

\begin{abstract}
Abstrak.
Berdasarkan hasil pengamatan tim pengabdian kepada guru-guru seni budaya SMP di Lampung Utara, didapatkan hasil bahwa sebagian besar guru seni budaya belum menguasai materi seni budaya itu sendiri. Hal ini dikarenakan oleh latar belakang pendidikan yang sebenarnya bukan dari latar belakang pendidikan seni. Mensiasati hal tersebut, maka tim berinisiatif untuk memberikan pelatihan tari dan musik iringan tari Sigeh Penguten. Sigeh Penguten merupakan sebuah tari tradisi Lampung yang sudah semestinya dikuasai oleh masyarakat Lampung terlebih anak-anak usia sekolah. Sebagai sebuah dasar untuk menjaga dan mengembangkan tradisi Lampung, oleh karena itu tari ini dipilih sebagai bahan pelatihan. Melalui pelatihan ini, guru-guru seni budaya tingkat SMP di Kabupaten Lampung Utara yang tergabung dalam Musyawarah Guru Mata Pelajaran Seni Budaya diharapkan mampu menguasai tari dan musik iringan tari Sigeh Penguten. Hal ini juga diharapkan dapat membantu guru-guru tersebut untuk melaksanakan mata pelajaran seni budaya di sekolah. Hasil pengabdian menunjukan bahwa setelah mengikuti pelatihan, guru seni budaya di Kabupaten Lampung Utara yang tergabung dalam forum MGMP dapat menarikan tari Sigeh Penguten dan mengiringinya dengan memainkan alat musik secara langsung. Namun tempo dari tari dan musik yang masih belum sesuai dengan yang sebenarnya, hal ini disebabkan karena masih pada tahapan pembelajaran.
\end{abstract}

Kata kunci.

pelatihan, Sigeh Penguten, seni budaya.

\section{PENDAHULUAN}

Sebagian besar guru seni budaya di provinsi Lampung bukanlah lulusan dari kualifikasi pendidikan seni budaya, baik itu guru tari, rupa, teater maupun musik. Guru-guru tersebut biasanya merupakan guru dengan bidang keahlian mata pelajaran lain yang tidak cukup jam mengajar lalu ditempatkan di mata pelajaran seni budaya. Hal ini sungguh menghambat pembelajaran. Pelajaran seni budaya yang seharusnya berisikan pengalaman empiris berkesenian bagi siswa kini hanya menjadi paparan pengetahuan yang juga bukan berasal

\section{* Corresponding author: nabilla.kurnia@fkip.unila.ac.id}

Received DD MM YYYY; Received in revised form DD MM YYYY; Accepted DD MM YYYY Available online DD MM YYYYY Lembaga Penelitian dan Pengabdian Kepada Masyarakat Universitas Lampung 
dari ahlinya [1]. Keadaan ini memang menyulitkan, mengingat banyaknya guru seni budaya yang dibutuhkan disekolah dan pembukaan formasi guru yang tidak sebanding. Hal ini terjadi hampir diseluruh kabupaten di Lampung, Lampung Utara salah satunya.

Sigeh Penguten merupakan salah satu tari tradisi daerah Lampung, yang merupakan bentuk tari penyambutan yang kemudian menjadi tradisi dalam setiap acara-acara penting di daerah provinsi Lampung [2]. Tari ini diiringi oleh musik dari talo balak yang juga merupakan alat musik tradisi masyarakat Lampung. Tari dan musik Sigeh penguten semestinya menjadi dasar yang dikuasai oleh siswa di provinsi Lampung sebagai pengalaman berkesenian dan salah satu wujud menjaga serta melestarikan budaya. Oleh karena itu sudah semestinya guru tari dan musik juga menguasai tari serta iringannya [3].

Tari dan musik Sigeh Penguten penting untuk dikuasai siswa Sekolah Menengah Pertama (SMP), karena anak-anak seusia tersebut perlu ditanamkan pengetahuan mengenai budaya dan tradisi yang berkembang dimasyarakat yang mana hal ini akan menjadi bekal mereka untuk kemudian menjaga kebudayaan dengan cara mengembangkannya di bangku sekolah menengah atas (SMA) [4]. Sedangkan pada jenjang sekolah Dasar anak-anak diberikan pemahaman berkesenian yang lebih eksprsif sesuai dengan karakter usianya. Berdasarkan pengamatan kepada Musyawarah Guru Mata Pelajaran Seni Budaya di kabupaten Lampung Utara, sebagian besar guru seni budaya tidak menguasai tari dan musik tari Sigeh Penguten. Maka, nerdasarkan hasil pengamatan tersebut dipandang perlu untuk dilakukan pembelajaran atau pelatihan tari Sigeh Penguten berikut pelatihan musik pengiringnya kepada guru seni budaya yang tergabung kedalam Musyawarah Guru Mata Pelajaran Seni Budaya tingkat SMP di Kabupaten Lampung Utara.

\section{METODE}

Metode pelaksanaan kegiatan ini dilakukan dengan 2 tahapan, pertama tahapan pra kegiatan yang berkenaan dengan ijin dan undangan ke mitra-mitra yang akan terlibat dalam kegiatan pengabdian, kedua saat pelaksanaan pelatihan. Pelaksanaan melibatkan tim pengabdian sebagai tutor atau pemateri sesuai dengan bidang kelimuan masing-masing. Adapun Metode yang digunakan dalam kegiatan pelatihan ini diantaranya adalah sebagai berikut:

1. Tes dalam kategori free tes, untuk mengetahui pengetahuan awal peserta dalam $[5,6]$ :

a. Pemahaman tentang tari Sigeh Penguten

b. Pemahaman tentang makna dan fungsi tari serta musik iringan tari Sigeh Penguten

c. Pemahaman menarikan tari Sigeh Penguten

d. Pemahaman memainkan musik iringan tari Sigeh Penguten

2. Metode Ceramah oleh tim pelaksana pengabdian kepada masyarakat untuk menjelaskan tentang tari Sigeh Penguten, makna dan fungsi musik iringan tari Sigeh Penguten.

3. Metode Demonstrasi oleh tim pelaksana untuk mempraktikan tari Sigeh Penguten dan mempraktikan permainan musik iringan tari sigeh penguten.

4. Bimbingan teknis oleh tim pelaksana untuk melatih peserta menarikan tari Sigeh Penguten dan memainkan musik iringan tari Sigeh Penguten. 


\section{Rencana Evaluasi}

\section{Evaluasi Awal}

Evaluasi awal ini digunakan untuk mengetahui kemampuan awal peserta mengenai seberapa jauh pengetahuan tentang materi.

\section{Evaluasi Proses}

Evaluasi ini dilaukan guna mengatahui kelancaran dan keberlangsungan pelatihan tari Sigeh Penguten dan musik iringan tari Sigeh Penguten.

\section{Evaluasi Hasil}

Post Tes tertulis, untuk mengetahui sejauh mana teori mengenai tari Sigeh Penguten dan musik iringan Tari Sigeh Penguten tersebut dikuasai oleh peserta.

Evaluasi tugas individu, evaluasi keterampilan menari tari Sigeh Penguten dan memainkan musik iringan tari Sigeh Penguten.

\section{Evaluasi Dampak}

Pemantauan dan monitoring setelah dua bulan kegiatan ini dilakukan, guna melihat hasil dari pelatihan.

\section{HASIL DAN PEMBAHASAN}

\section{Hasil Kegiatan}

Program pengabdian ini berjudul Pelatihan Musik dan Tari Sigeh Penguten Kepada Forum Musyawarah Guru Mata Pelajaran Seni Budaya Tingkat SMP di Lampung Utara. Kegiatan ini semula dijadwalkan pada bulan Agustus harus mengalami perubahan dikarenakan situasi Lampung Utara yang melaksanakan Pemberlakuan Pembatasan Kegiatan Masyarakat (PPKM). Oleh karena itu kegiatan pelatihan ini harus diundur dan dilaksanakan pada tanggal 1-3 September 2021 di SMPN 7 Kotabumi Lampung Utara. Disebabkan oleh PPKM juga peserta dari kegiatan ini dibatasi untuk memenuhi syarat protokol kesehatan. Peserta tersebut adalah guru seni budaya perwakilan dari beberapa SMP yang tersebar di seluruh kecamatan yang ada di Kabupaten Lampung Utara.

Kegiatan pelatihan ini berlangsung selama tiga hari, meliputi materi pemahaman tentang kebudayaan Lampung khususnya Lampung Utara yang dapat dijadikan bahan pembelajaran di kelas, pembelajaran tari Sigeh Penguten dan pembelajaran musik tari Sigeh Penguten. Penyampaian materi dilakukan oleh pemateri yang kompeten dalam bidang seni tari dan juga musik khususnya tradisi Lampung. Pemberian materi tari diberikan oleh Nabilla Kurnia Adzan, M.Pd dan Dwi Tiya Juwita, M.Pd yang merupakan dosen di Program Studi Pendidikan Tari FKIP Universitas Lampung. Materi musik diberikan oleh Erizal Barnawi, M.Sn yang juga merupakan dosen di Fakultas Keguruan dan Pendidikan Universitas Lampung Program Studi Pendidikan Musik. Berikut akan diuraikan pelatihan sejak hari pertama hingga hari ketiga.

\section{Pelatihan Hari Pertama}

Pelatihan dibuka langsung oleh Kepala Dinas Pendidikan dan Kebudayaan yang juga didampingi oleh ketua Musyawarah Kerja Kepala Sekolah tingkat SMP di Lampung Utara. Pada sambutannya Kepala Dinas Pendidikan dan Kebudayaan Kabupaten Lampung Utara bapak Drs. Mat Soleh, M.Pd sangat mengapresiasi kegiatan ini dan berharap guru-guru seni budaya SMP di Lampung Utara dapat mengikuti pelatihan dengan baik, sehingga 
pembelajaran seni budaya di sekolah dapat menjadi lebih baik dari sebelumnya. Kegiatan pelatihan dilanjutkan dengan pemaparan materi mengenai musik tradisional Lampung yang disampaikan oleh bapak Erizal Barnawi, M.Sn.

Kegiatan dilanjutkan dengan pemaparan materi mengenai tari Sigeh Penguten secara teori yang meliputi sejarah tari Sigeh Penguten, siapa penciptanya, nama-nama ragam gerak tari Sigeh Penguten, perkembangan tari Sigeh Penguten dan bagaimana aplikasi tari ini dalam Pembelajaran Seni Budaya disekolah. Sebagian besar guru-guru seni budaya di Lampung Utara tidak memiliki latar belakang pendidikan Seni Budaya, sehingga pemaparan materi yang dilakukan sangat berjalan dengan kondusif. Materi mengenai tari Sigeh Penguten ini disampaikan oleh Nabilla Kurnia Adzan, M.Pd. mengenai sejarah, perkembangan dan tari Sigeh Penguten secara teoritis.

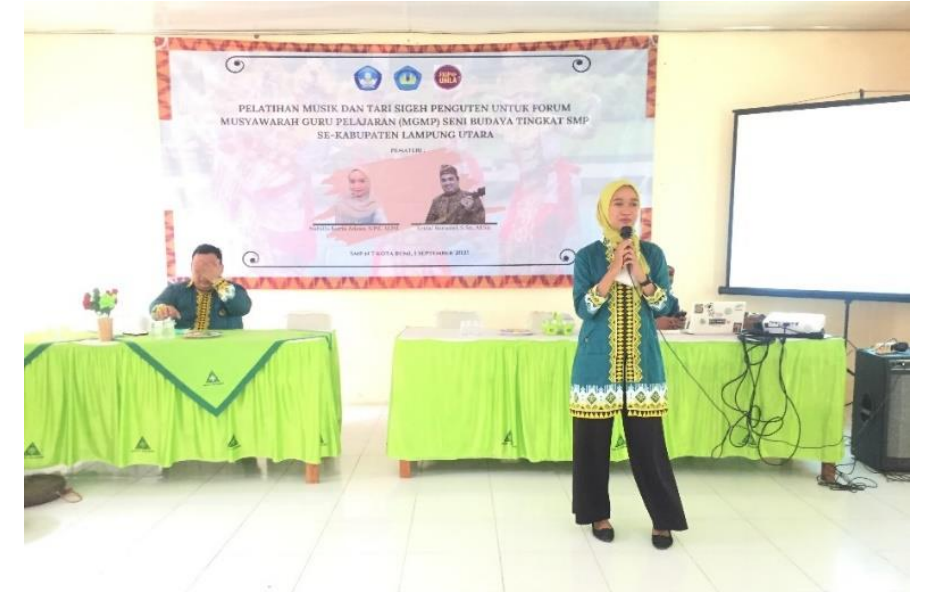

Gambar 1. Penyampaian Materi Musik dan Tari Sigeh Penguten secara Teoritis

\section{Pelatihan Hari Kedua}

Pada hari kedua ini dilakukan praktik langsung bermain alat musik Talo Balak dengan materi musik pengiring tari Sigeh Penguten dan praktik berlatih tari Sigeh Penguten. Para peserta dibagi menjadi dua kelompok berdasarkan hasil wawancara diawal pelatihan mengenai latar belakang minat dan bakat. Tujuh orang peserta mengikuti pelatihan Tari Sigeh Penguten yang terdiri dari enam guru wanita dan satu guru laki-laki. Lalu delapan peserta lainnya mengikuti pelatihan musik tari Sigeh Penguten dengan tujuh orang guru wanita dan satu orang guru laki-laki.

Pelatihan tari dilakukan diruang aula seni budaya SMP N 7 Kotabumi. Pelatihan dibuka dengan melihat kemampuan menari guru-guru tersebut, dan hasilnya semua guru seni budaya yang mengikuti pelatihan tari sebelumnya pernah mengetahui tari Sigeh Penguten namun belum pernah praktik menari secara langsung, oleh karena itu pelatihan dilakukan dengan mengenalkan tari Sigeh Penguten per-ragam gerak. Kegiatan ini dilakukan dengan metode demonstrasi, pelatih mencontohkan gerakannya lalu diikuti dengan para peserta, selain itu digunakan juga metode drill atau latihan untuk memperlancar gerakan yang telah diberikan oleh pemateri. Peserta pelatihan tari terlihat antusias mempelajari dan secara mudah dapat mengikuti gerakan pergerakan. Walaupun secara teknik tari masih belum baik. 


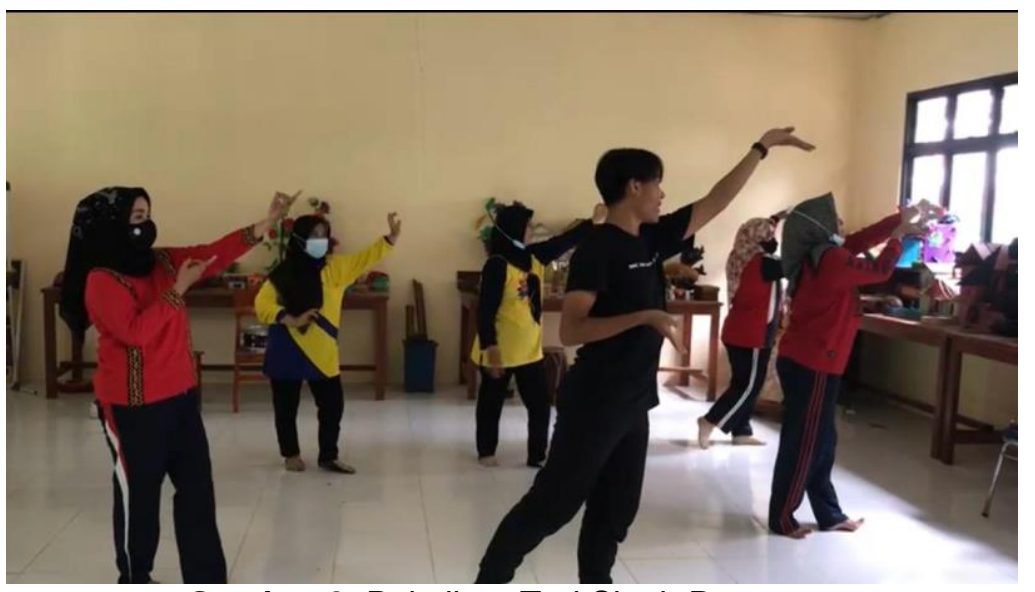

Gambar 2. Pelatihan Tari Sigeh Penguten

Selama pelatihan tari berlangsung, peserta lainnya melakukan pelatihan musik tari Sigeh Penguten diruangan yang berbeda dengan dibimbing oleh bapak Erizal Barnawi, M.Sn. Pelatihan dilakukan dengan praktik langsung memainkan alat musik Talo Balak. Pada dasarnya musik tari sigeh penguten memiliki banyak repetisi dalam bentuknya, hanya terdapat dua ragam tabuhan pada Musik tari Sigeh Penguten yaitu tabuh gupek dan tabuh tari. Kedua tabuhan tersebut dipelajari secara langsung hari itu. Metode yang digunakan sama dengan metode pada tari yaitu motede demonstrasi dan drill. Pemateri terlebih dahulu mencontohtakan cara bermain lalu diikuti oleh para peserta. Mengingat talo balak memiliki beberapa jenis instrument maka dalam hal ini bapak Erizal Barnawi, M.Sn dibantu oleh dua orang mahasiswa untuk mengarjarkan kedua tabuhan tari Sigeh Penguten ini.

Selain menggunakan metode demonstrasi dan drill, pelatihan musik juga berlangsung dengan pemberian notasi angka kepada para peserta. Hal ini dilakukan agar para peserta dapat melihat notasi sambil bermain alat musik, yang kemudian dilakukan berulang agar semakin memperlancar permainan talo balak tersebut. kesulitan yang dialami dalam pelatihan musik adalah ketika peserta harus bermain sesuai denhan notasi dan tempo, yang mana hal ini membutuhkan kekompakan dan latihan yang serius. Namun guru-guru peserta pelatihan dapat melakukannya dengan cukup baik. Dari kedua tabuhan yang ada pada tari Sigeh Penguten, peserta lebih dominan menguasai tabuh gupek dibandingkan tabuh tari. Hal ini dikarenakan oleh tabuh gupek dilakukan lebih sebentar dari pada tabuh tari sehingga kesalahan yang terjadi sangat minim.

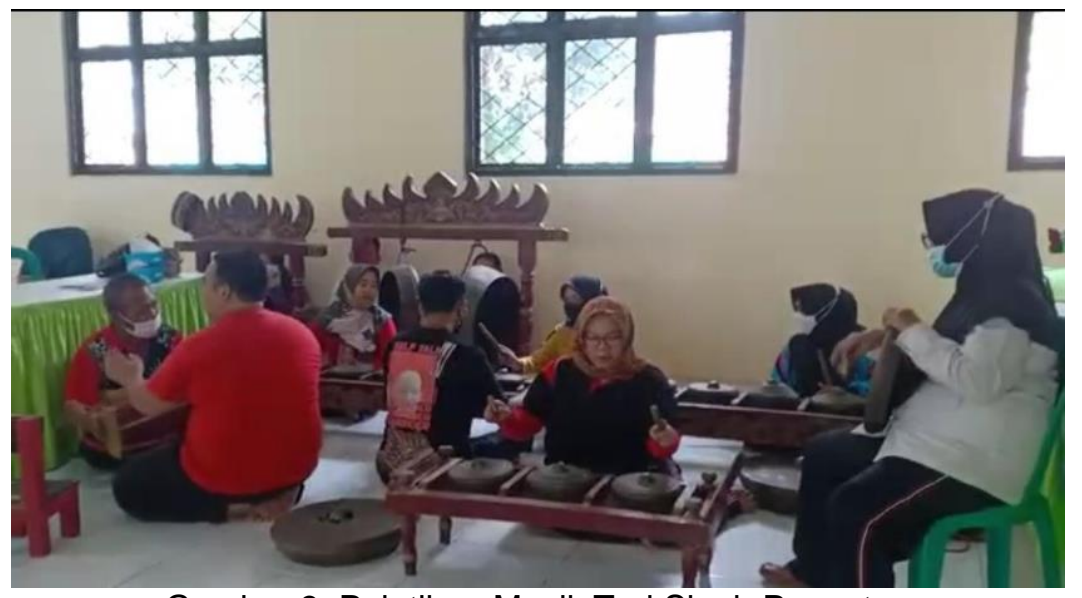

Gambar 3. Pelatihan Musik Tari Sigeh Penguten 


\section{Pelatihan Hari Ketiga}

Setelah dua hari pelatihan dilakukan secara tatap muka atau luring, maka pelatihan dilanjutkan dengan kegiatan tatap maya atau daring. Pelatihan dilanjutkan dengan memberikan video tutorial pembelajaran musik dan tari Sigeh Penguten dan pelatihan dilanjtkan dengan pembelajaran mandiri. Lalu hasil dari pembelajaran mandiri tersebut dikumpulkan, untuk melihat perkembangan dari para peserta terhadap musik dan tari Sigeh Penguten. Selain digunakan untuk memeprlancar materi pelatihan, video tutorial yang diberikan juga dapat menjadi media pembelajaran di sekolah. Guru dapat memberikan media tersebut pada saat proses belajar mengajar berlangsung, sehingga siswa dapat belajar gerak tari Sigeh Penguten dan guru dapat mengawasi pembelajarn tersebut karena sudah memiliki pengalaman belajar tarinya secara langsung.

\section{Pembahasan}

Pelatihan mudik dan tari Sigeh Penguten bagi forum Musyawarah Guru Mata Pelajaran Seni Budaya tingkat SMP se-Kabupaten Lampung Utara bertujuan untuk meningkatkan kompetensi professional guru seni budaya. Sebagai guru seni budaya maka salah satu kompetensi professional yang harus dipenuhi adalah dengan menguasai materi dan bahan ajar. Tari Sigeh Penguten yang merupakan tari tradisional masyarakat Lampung adalah salah satu materi dan bahan ajar pada mata pelajaran seni budaya yang berbasis kearifan lokal. Maka sudah menjadi kewajiban bagi para guru seni budaya menguasai musik dan tari Sigeh Penguten.

Telah dijelaskan pada bab sebelumnya mengenai hasil observasi awal mengenai kondisi guru seni budaya di Lampung khususnya Lampung Utara yang menunjukan hasil bahwa sebagain besar guru seni budaya tidak menguasai bidang seni. Hal ini dikarenakan latar belakang pendidikan yang tidak sesuai, banyak guru seni budaya di sekolah yang hanya mengisis kekosongan dari kewajiban mengajarnya dengan mengajar seni budaya. Hasil observasi awal juga sesuai dengan hasil wawancara yang dilakukan oleh tim sebelum kegiatan pelatihan berlangsung, bahwa banyak guru seni budaya yang hanya mengetahui tari Sigeh Penguten namun tidak bisa melakukannya. Sehingga pembelajaran disekolah hanya dilakukan secara apresiatif bukan kepada praktik langsung yang seharusnya dilakukan di mata pelajaran seni budaya.

Kegiatan pelatihan ini diikuti oleh 15 orang peserta yang mewakili beberapa SMP di Kabupaten Lampung Utara. Jumlah peserta yang terbatas dikarenakan oleh masih diberlakukannnya PPKM. Antusias para peserta terhadap pelatihan sangat baik, hal ini dapat dilihat dari konsistensi peserta mengikuti semua rangkaian kegiatan pelatihan sampai selesai dan mengamati setiap materi yang diberikan. Pembelajaran tari berlangsung dengan kondusif, hal yang menjadi penghambat adalah dari segi usia para peserta pelatihan yang tidak lagi muda maka pelatihan tari harus dilakukan secara lebih lambat dan melakukan banyak pengulangan, namun hal ini tidak mengurangi emangat para peserta untuk menghafal gerak demi gerak dari tari Sigeh Penguten yang diberikan, sehingga para peserta kemudian dapat melakukan gerak tari Sigeh Penguten dengan cukup baik.

Pada pelatihan musik juga berjalan dengan lancar, para peserta terliht antusias dalam mengikuti jalannya pelatihan. Hal ini juga disebabkan oleh factor pelatihan yang dilakukan langsung dengan alat musik talo balak. Tidak banyak sekolah yang memiliki alat ini, sehingga para peserta terlihat sangat bersemangat. Namun alasan para peserta semangat ini kemudian sekaligus menjadi hambatan, hal-hal yang didapatkan pada pelatihan kemudian tidak bisa dipraktikan langsung disekolah karena keterbatasna fasilitas. Namun hal ini sudah dikomunikasikan oleh forum MGMP kepada Kepala Dinas Pendidikan dan 
Kebudayaan Lampung Utara pada kegiatan pelatihan, untuk kiranya memberikan alat musik talo balak kesetiap sekolah untuk mendukung pembelajarn snei budaya yang berbasis kearifan lokal.

Berdasarkan hasil belajar berupa video menari yang dikirimkan peserta dapat dikatakan terdapat peningkatan kemampuan. Hal ini didasari dari hasil wawancara awal, pengamatan saat pelatihan berlangsung dan pengamatan video hasil belajar para peserta. Hal ini diharapkan dapat menjadi kontribusi dalam upaya meningkatkan kompetensi professional guru seni budaya dalam forum MGMP Seni Budaya tingkat SMP di Lampung Utara.

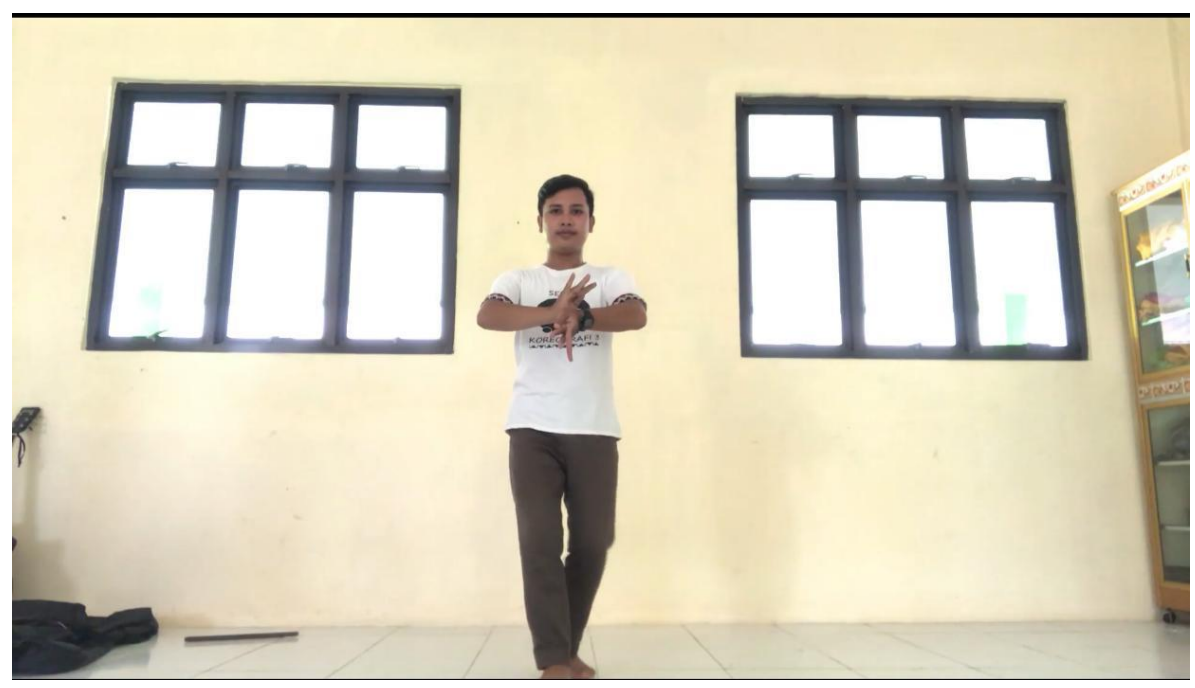

Gambar 4. Video latihan mandiri peserta pelatihan

Gambar 4. di merupakan cuplikan gambar dari video latihan dari para eserta pelatihan yang kemudian dikirimkan kepada tim pengabdian, untuk kemudian dikoreksi. Berdasarkan videp-video yang dikrimkan, sebagain besar peserta pelatihan sudah dapat melakukan praktik gerak tari Sigeh Penguten dengan baik. Kekurangan terbesar terletak pada kesesuaian gerak dan musik atau tempo. Hal ini disebabkan oleh kurangnya latihan secara terus menerus. Dalam berlatih tari membutuhkan waktu yang cukup banyak untuk terus melatih kemampuan menari untuk dapat selaras dengan segala unsur pendukungnya.

\section{KESIMPULAN}

Berdasarkan hasil kegiatan Pengabdian Kepada Masyarakat yang telah dilakukan kepada forum MGMP Seni Budaya tingkat SMP di kabupaten Lampung Utara dapat ditarik kesimpulan bahwa pelatihan musik dan tari Sigeh Penguten dapat memberikan pengetahuan serta pengalaman baru dalam pemahaman musik dan gerak tari Sigeh Penguten. Tidak hanya pemahaman bahkan para guru seni budaya tersebut dapat mempraktikan langsung tariannya dan musik pengiringnya. Dari hasil belajar melalui video yang dikirimkan juga sebagian besar peserta telah dapat menghafal gerak tari Sigeh Penguten yang kemudian dapat digunakan untuk pembelajarn Seni Budaya di sekolah masing-masing.

\section{DAFTAR PUSTAKA}

[1] Jamalus dan Hamzah Busroh. (2012). Pendidikan Kesenian 1, Dirjen Pendidikan Tinggi Proyek Pembinaan Tenaga Pendidikan.

[2] Arsana, I Gusti Nyoman. (2009). Deskripsi Musik Pengiring Tari Sigeh Penguten. Bandar Lampung. UPTD Taman Budaya. 
[3] Raji Aripin, Dkk. (1991). Titilaras Talo Balak. Bandar Lampung: Taman Budaya Lampung.

[4] Azzahra, Fatimah. (2017). Revitalisasi Tari Sigeh Penguten Melalui Pendidikan Seni Budaya di SMP N 1 Tanjung Raya Kabupaten Mesuji. Semarang: Jurnal Catarsis Vol 6. No 1. (38-48).

[5] Mustika, I Wayan. 2012. Teknik Dasar Gerak Tari Lampung. Bandar Lampung: Aura Publishing.

[6] Barnawi, Erizal. (2018). Notasi Pembelajaran Musik Tradisional Gamolan Pekhing Sekala Brak Lampung. (Bandar Lampung: Aura Publishing). 